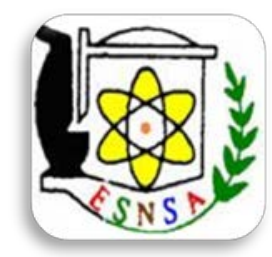

Arab Journal of Nuclear Sciences and Applications

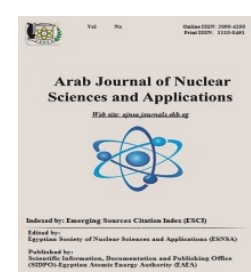

(ESNSA)

\title{
Using Thorium Based Fuel in AP1000: Steady State Analysis
}

\author{
H. K. Selim', E. H. Amin ${ }^{1}$, H. E. Roushdy ${ }^{2}$ \\ (1) Department of Nuclear Safety Engineering, Nuclear and Radiological Regulatory Authority, Cairo, Egypt \\ (2) Engineering Physics Department, Faculty of Engineering, Cairo University, Giza, Egypt
}

Received $23^{\text {rd }}$ Oct. 2017 The feasibility of utilizing Thorium-Plutonium Mixed Oxide in the Westinghouse AP1000 Advanced Accepted $3^{\text {rd }}$ June 2018 Passive pressurized water reactor is examined under steady-state, beginning of life (BOL) conditions. Initial core loading of the reactor consists of three types of $\mathrm{UO}_{2}$ fuel assemblies with different enrichment in U235, as follows: $2.35 \mathrm{w} / \mathrm{o}, 3.40 \mathrm{w} / \mathrm{o}$ and $4.45 \mathrm{w} / \mathrm{o}$. In this paper, one-third of the $\mathrm{UO}_{2}$ fuel assemblies are replaced by (Th-Pu) $\mathrm{O}_{2}$ fuel assemblies in two arrangements: the first one assumes a blanket of (Th-Pu)O $\mathrm{O}_{2}$ fuel which replaces the $4.45 \%$ enriched $\mathrm{UO}_{2}$ fuel assemblies surrounding the low enriched $\mathrm{UO}_{2}$ fuel assemblies, and in the second arrangement some of the $\mathrm{UO}_{2}$ fuel assemblies are replaced in a way creating a ring of (Th-Pu) $\mathrm{O}_{2}$ fuel in the core. The reactor is modeled using QUARK computer code. The required cross-section data for QUARK calculations have been generated using WIMSD5 lattice cell code. The results of the steady state analysis show that introducing $\left(\mathrm{Th}-\mathrm{Pu} \mathrm{O}_{2} \mathrm{fuel}\right.$ into AP1000 would not negatively impact the reactor's safety as the criteria mentioned in design control document are met. For (Th-Pu) $\mathrm{O}_{2}$ fuel blanket and ring loading arrangements, the calculated power peaking factor is less or equal to the design limit. Over the length of the hot channel, the Minimum Departure from Nucleate Boiling Ratio (MDNBR) varies with a minimum above the design limit for the considered (Th-Pu) $\mathrm{O}_{2}$ fuel assemblies loading arrangements. This work provides the basis for studying Th-based fuel behavior and thermal hydraulic analysis of AP1000 using Th-based fuel in order to evaluate the safety aspect of various core loading patterns under anticipated and accidental conditions.

Keywords: AP1000; Reactor Safety; Steady-State Analysis; (Th-Pu) $\mathrm{O}_{2}$ fuel; Neutronic/Thermal-Hydraulic Coupling; QUARK; WIMSD5

\section{Introduction}

Due to the scarcity of natural uranium resources and a mismatch between the uranium production and the requirements for reactors operation, thorium has been explored as an alternative nuclear fuel to be used in thermal reactors. Past decades of extensive operation of Light Water Reactors (LWRs) have created significant amounts of plutonium, which could be either utilized in future fast reactor systems or stored in final repository. Current practice of $\mathrm{Pu}$ recycling in the existing LWRs in the form of U-Pu mixed oxide fuel (MOX) is not efficient due to continuous $\mathrm{Pu}$ production from U-238. Consequently, other methods have been proposed to reduce the plutonium stockpile, such as mixing plutonium with thorium or other inert materials. The use of Th-Pu mixed oxide fuel will considerably improve $\mathrm{Pu}$ consumption rates because no new $\mathrm{Pu}$ is generated from Th $[1,2]$. Th-Pu mixed oxide fuel is anticipated to have a more favorable in-core behavior as compared to MOX fuel, due to its better material properties, including a higher thermal conductivity, a significantly higher melting point, a lower thermal expansion coefficient, and a lower fission-gas release [3].

Preliminary calculations have been carried out by Klara Insulander Bjork [4] to investigate the possibility of extending operating cycle length in 
PWRs using of Th-Pu mixed oxide fuel. The calculations have been carried out in two dimensions, utilizing the fuel assembly burnup simulation program CASMO-5. The reload scheme and the operating parameters are modeled on the Swedish PWR Ringhals 3, and a normal UOX fuel assembly designed for this reactor has been used as a reference. Results have shown that an extension of the currently employed 12-month operating cycle length is possible, either through using a burnable absorber or with a modified fuel assembly design, assuming the same 3-batch reload scheme as the one currently used in Ringhals 3 PWR. The initial $k_{\text {inf }}$ of the new (Th$\mathrm{Pu}$ ) mixed oxide fuel project was designed not to exceed the $\mathrm{k}_{\text {inf }}$ value corresponding to the reference UOX fuel. The calculated power peaking factor is much lower than the reference ones value, but slightly increases with the burn up of the fuel assembly. The calculated values for all reactivity coefficients were within acceptable range. The worth of control rods and soluble boron are lower than the reference, as expected for a plutoniumbearing fuel. CheukWah Lau et al. [5] studied the safety aspects of introducing (Th-Pu) mixed oxide fuel in PWRs for two different cases, namely: a full (Th-Pu) mixed oxide core, and a reactor core containing $1 / 3$ (Th-Pu) mixed oxide fuel in combination with the ordinary UOX fuel. It has been shown that the basic safety limits are contained in both cases, but the lower amount of $\mathrm{Pu}$ loaded in the 1/3 (Th-Pu) mixed oxide core compared with a full (Th-Pu) mixed oxide core will result in a lower consumption rate of plutonium. However, the lower requirements of control rods and enriched boron, higher fraction of delayed neutrons, reactivity feedback more similar to that of a UOX core, and higher plutonium incineration compared with 30\% UOX/MOX core make the implementation of the $1 / 3$ (Th-Pu) mixed oxide core more attractive for initiating plutonium incineration in currently operating commercial LWRs. Additionally, the damping of axial xenon oscillations is more effective for the $1 / 3$ (Th-Pu) mixed oxide core compared with the standard core. The strategy of using $1 / 3$ (Th-Pu) mixed oxide leads to a cheaper and easier way to start using (Th-Pu) mixed oxide fuel assemblies in the near future for reducing the plutonium stockpile. Naymushin et al. [6] explored the possibilities of using alternative thorium-based fuel compositions in VVER-type reactors. This study presents a comparison between standard uranium dioxide fuel and perspective fuel composition: thorium dioxide, mixed thorium and plutonium dioxides. The calculation results have shown that using of perspective fuel composition lead to improving reactor core physical and economical characteristics. Furthermore, the investigated fuel provides effective burnup that increases the fuel cycle length.

Safety performance of the reactor at steady state represents the basis for the analysis of the reactor under transient. Fuel characterization under normal operating conditions (steady state conditions) is fundamental, as input data, for studying the fuel behavior under anticipated and accidental conditions [7]. The increased importance of detailed reactor core and fuel assembly description for LWRs, as well as the sub-channel safety analysis, requires coupled neutronic/thermalhydraulic codes. Omid Noori-Kalkhoran et al. [8] analyzed VVER-1000 nuclear reactor core by using the neutronic/thermal hydraulic coupling calculations approach. This calculation approach is based on PARCS v2.7, COBRA-EN and WIMSD5B computer codes. First, WIMSD-5B lattice cell code has been used to calculate macroscopic crosssections for each fuel assembly. Neutronic parameters of interest have been calculated by means of PARCS v2.7 code. COBRA-EN was used for thermal-hydraulic parameters calculations for all the fuel assemblies. The proposed coupling can be applied for both steady-state and transient calculations. Neutronic accidents such as REA (Rod Ejection Accident) and thermal-hydraulic accidents such as LOFA (Loss of Flow Accident) can be analyzed by the proposed coupling. In the above mentioned study, steady-state calculations and LOFA have been simulated. The results have been compared to Bushehr Nuclear Power Plant (Iran) Final Safety Analysis Report - FSAR. The results are very similar to those included in FSAR, and confirm the ability of this package to simulate an accident in the reactor core, especially, a thermal-hydraulic accident that is out of the capability of PARCS code, used individually.

\section{Description of the Reactor}

AP1000 is an advanced passive pressurized water reactor designed to produce 1117 MWe $(\sim 3400$ MWth). AP1000 core is composed of 157 fuel assemblies. Each assembly consists of 264 fuel 
rods, 24 control rod guide tubes and one central instrumentation guide tube, arranged in a $17 \mathrm{x} 17$ square array. AP1000 core design uses discrete burnable absorbers (PYREX) and integral fuel burnable absorbers (IFBA). PYREX rod is made of borosilicate glass, whereas IFBA rod is a fuel rod with thin boride coating on the fuel. These rods are arranged in different patterns within a fuel assembly and their function is to partly control the core excess reactivity, to limit power peaking factors and to keep the moderator temperature coefficient (MTC) negative at normal operation $[9,10]$.

In order to control relatively rapid reactivity changes and axial power distribution, rod cluster control assemblies (RCCA) are used. AP1000 core contains 69 RCCA, each of these assemblies is consisted of 24 absorber rods. Two types of control rod cluster assemblies are used, i.e. black and gray. Absorber material of black rod is an alloy of Ag-In-Cd in stainless steel clad. The gray rod cluster assembly is similar to the black rod cluster control assembly except that 12 of the 24 rods are fabricated of stainless steel, while the remaining 12 rods are Ag-InCd (of a reduced diameter as compared to the one of RCCA absorber) with stainless steel clad. The gray rod cluster assemblies are used in load follow maneuvers and are named 'Mechanical Shim (MSHIM)', as their operation minimizes the need for changes to the concentration of soluble boron $[9,10]$. AP1000 design parameters are given in Table(1).

Table (1): AP1000 Design Parameters

\begin{tabular}{|l|l|}
\hline Parameters & Value \\
\hline Reactor core heat output & $3400 \mathrm{MW}_{\text {th }}$ \\
\hline System pressure, nominal & $2250 \mathrm{psia}$ \\
\hline $\begin{array}{l}\text { System pressure, minimum steady } \\
\text { state }\end{array}$ & $2190 \mathrm{psia}$ \\
\hline Average inlet mass flux & $12.45 \times 10^{6} \mathrm{~kg} / \mathrm{hr}^{-\mathrm{m}^{2}}$ \\
\hline Coolant nominal inlet temperature & $552.594 \mathrm{~K}$ \\
\hline Coolant average temperature in core & $576.539 \mathrm{~K}$ \\
\hline Average linear power & $18.77 \mathrm{~kW} / \mathrm{m}$ \\
\hline Core diameter, equivalent & $304.04 \mathrm{~cm}$ \\
\hline Core height, cold, active fuel & $426.72 \mathrm{~cm}$ \\
\hline
\end{tabular}

\section{Initial core loading}

AP1000 initial core loading configuration, obtained from AP1000 Designed Control Documents (DCD)[9], is consisted by three types of $\mathrm{UO}_{2}$ fuel assemblies, with different enrichments in $\mathrm{U}^{235}$, namely: $2.35 \mathrm{w} / \mathrm{o}, 3.40 \mathrm{w} / \mathrm{o}$ and $4.45 \mathrm{w} / \mathrm{o}$. The highest enriched fuel assemblies are loaded at the core periphery, the other two lower enriched fuel assemblies being arranged in a checkboard pattern in the central portion of core. IFBA rods are distributed in a symmetrical pattern to reduce the pin to pin power peaking. PYREX rods are removable burnable absorbers. Fig.(1) presents the core configuration with fuel, PYREX and IFBA rods. Initial core parameters are given in Table (2).

\section{Modeling Methodology}

In this study, calculations were performed using QUARK, (QUAndry based Reactor Kinetics) computer code. QUARK is a combined computer program including a revised version of the QUANDARY three-dimensional, two-group neutron kinetics code and an upgraded version of the COBRA transient core analysis code (COBRAEN) [11]. The required cross-section data for QUARK have been generated using WIMSD5 code. WIMS (Winfrith Improved Multigroup Scheme) is a multigroup transport code for reactor lattice calculations, including burnup. WIMS has been extensively used throughout the world for power and research reactors lattice analysis [12]. A zero burnup with no Xenon and Samarium effects is assumed everywhere (i.e., B.O.L condition) and the node-dependent burnup weighted coolant densities are set equal to the correspondent instantaneous coolant densities, as soon as they are computed by the thermal-hydraulic model (COBRA-EN model).

A steady state calculation is performed in subcooled conditions (possible subcooled voids have been neglected by selecting the homogeneous model for the steam fraction), the computed Boron concentration was expected to be uniform throughout the core. A single Boron concentration is given in the input and used everywhere to update the nodal cross-sections.

\section{Reactor core modeling}

In this paper, in addition to AP1000 initial core loading, alternative core loadings are proposed, assuming that one-third of the $\mathrm{UO}_{2}$ fuel assemblies are replaced by (Th-Pu) $\mathrm{O}_{2}$ fuel assemblies in two arrangements. In first arrangement, a blanket of (Th-Pu) $\mathrm{O}_{2}$ fuel assemblies replaces the $4.45 \%$ enriched $\mathrm{UO}_{2}$ fuel assemblies (placed at the core periphery) and surrounds the low enriched $\mathrm{UO}_{2}$. In 
the second arrangement, some of the $\mathrm{UO}_{2}$ fuel assemblies are replaced creating a ring of (Th$\mathrm{Pu} \mathrm{O}_{2}$ fuel assemblies in the core. The core configurations used in the proposed analysis are shown in Fig. (2) and the material compositions of (Th-Pu) $\mathrm{O}_{2}$ fuel are as follows:

Material compositions (atoms/barn.cm): 5\% $\mathrm{PuO}_{2}+95 \% \mathrm{ThO}_{2}$

$\begin{array}{cl}\text { Th-232 } & \text { 2.0592E-2; } \\ \text { Pu-238 } & \text { 2.2900E-5; } \\ \text { Pu-239 } & \text { 7.4780E-4; } \\ \text { Pu-240 } & 2.9030 E-4 ; \\ \text { Pu-241 } & 1.5340 E-4 ; \\ \text { Pu-242 } & 5.0100 E-5 ; \\ \text { O-16 } & 4.3710 E-2\end{array}$

The three core loading schemes were modeled using QUARK code capabilities; radially, the core is divided into cells of $21.4 \mathrm{~cm}$ width, each corresponding to one fuel assembly, plus a radial reflector cell of the same width. Axially, the reactor core is divided into 23 layers; the top and bottom layers (reflector) have a thickness of 25.4 $\mathrm{cm}$ and the inner 21 layers have a thickness of $20.32 \mathrm{~cm}$ each. Each node of the reactor geometry is associated to one of the defined compositions. A complete set of macroscopic cross-sections for transport, scattering, absorption and fission is defined for each composition. Table (3) shows the 2-group macroscopic cross-section for each composition considered for the fuel assemblies in the core.

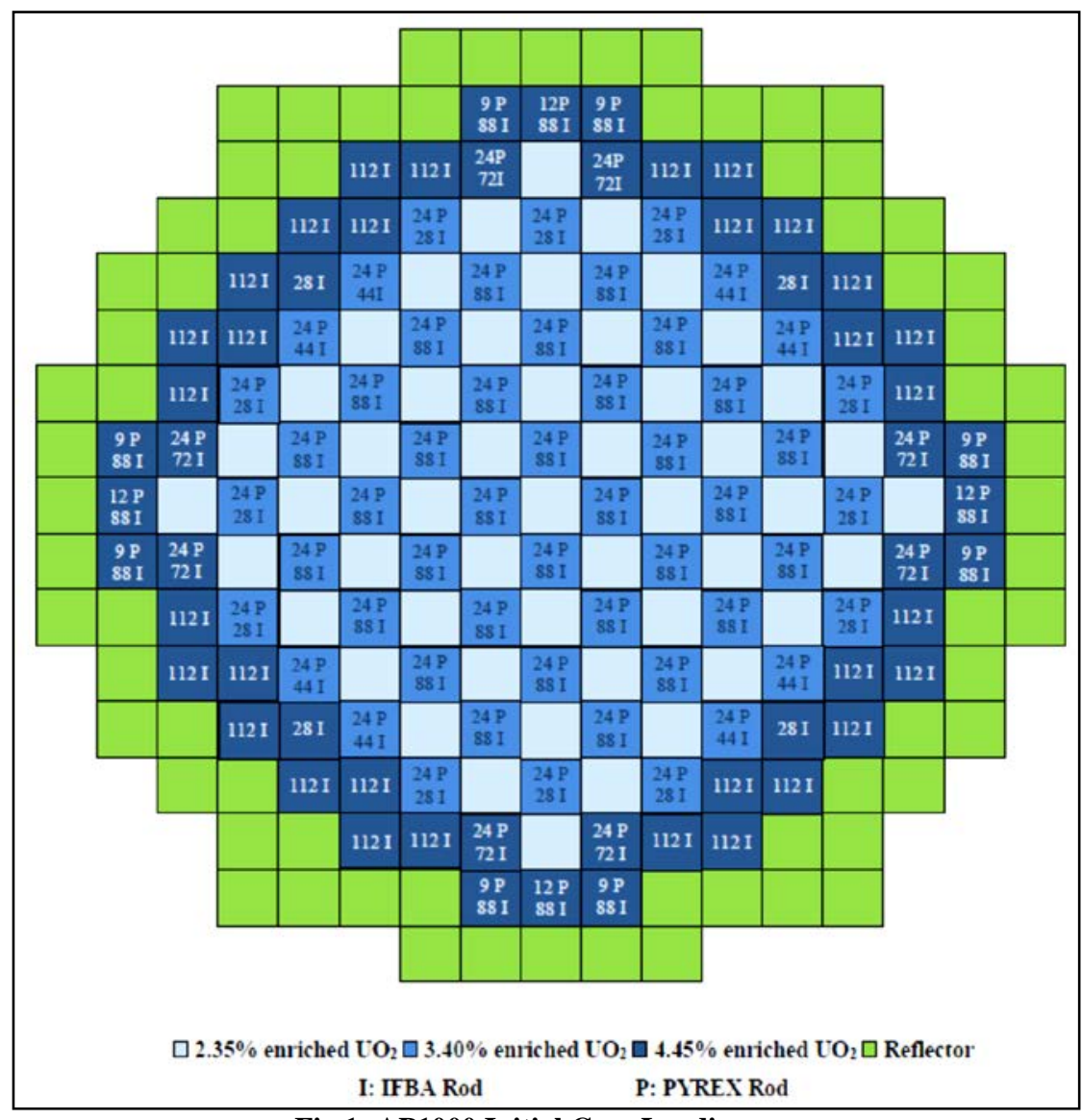

Fig.1: AP1000 Initial Core Loading 
Using Thorium Based Fuel In AP1000.....

Table (2): AP1000 Core Parameters

\begin{tabular}{ll}
\multicolumn{2}{c}{ Table (2): AP1000 Core Parameters } \\
\hline Fuel assemblies & \\
\hline Number & 157 \\
Rod array & $17 \mathrm{X} 17$ \\
Rods per assembly & 264 \\
Rod pitch (cm) & 1.26 \\
\hline Fuel rods & \\
\hline Number & 41,448 \\
Outside diameter (cm) & 0.95 \\
Diameter gap (cm) & 0.0165 \\
Clad thickness (cm) & 0.0572 \\
Clad material & ZIRLO \\
Fuel pellets diameter (cm) & 0.8191 \\
\hline Rod cluster control assemblies & \\
\hline Absorber material & Ag-In-Cd \\
Diameter (cm) & 0.866 \\
Cladding material & $304 \mathrm{SS}$ \\
Clad thickness (cm) & 0.047 \\
Number of clusters & 53 \\
Absorber rods per cluster & 24 \\
\hline Gray rod cluster control assemblies & \\
\hline Absorber material & Ag-In-Cd / 304SS \\
Diameter (cm) & 0.406 \\
Cladding material & $304 \mathrm{SS}$ \\
Clad thickness (cm) & 0.047 \\
Number of clusters & 16 \\
Absorber rods per cluster & 12 Ag-In-Cd / 12 304SS \\
\hline Discrete burnable absorber rods (PYREX) & \\
\hline Material & Borosilicate Glass \\
Outer diameter (cm) & 0.968 \\
Inner tube, Outer diameter (cm) & 0.461 \\
Clad and inner tube material & Stainless Steel \\
B 10 content (Mg/cm) & 6.24 \\
Absorber length (cm) & 145 \\
\hline Integrated fuel burnable absorber (IFBA) & \\
\hline Material & Boride Coating \\
B 10 content (Mg/cm) & 0.772 \\
Absorber length (cm) & 152 \\
\hline & \\
\hline
\end{tabular}

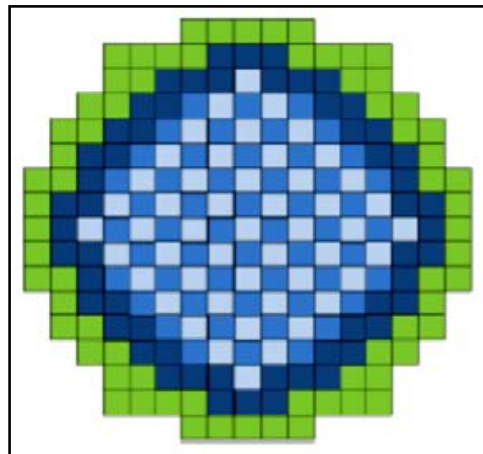

(a)

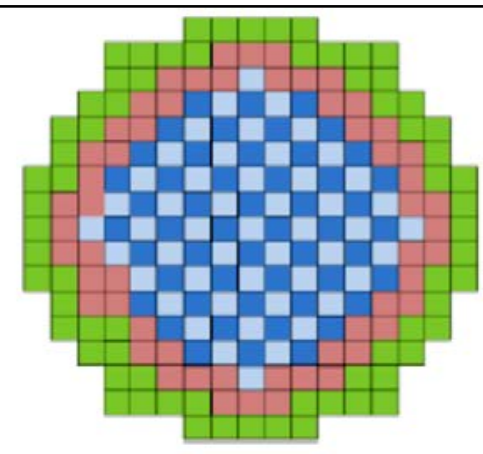

(b)

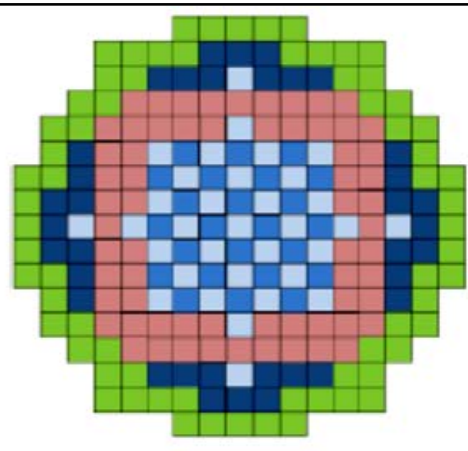

(c)

(a) $100 \% \mathrm{UO}_{2}$ (b) $\mathrm{UO}_{2} /(\mathrm{Th}-\mathrm{Pu}) \mathrm{O}_{2}$ - blanket (c) $\mathrm{UO}_{2} /(\mathrm{Th}-\mathrm{Pu}) \mathrm{O}_{2}$ - ring

$\square 2.35 \%$ enriched $\mathrm{UO}_{2} \square 3.40 \%$ enriched $\mathrm{UO}_{2} \square 4.45 \%$ enriched $\mathrm{UO}_{2} \square \mathrm{UO}_{2} /($ Th- $\mathrm{Pu}) \mathrm{O}_{2} \square$ Reflector

Fig.(2): Core Loading Patterns 
Table (3-a): Macroscopic Cross -section - $\mathrm{UO}_{2}$ Fuel Initial Compositions

\begin{tabular}{|c|c|c|c|c|c|}
\hline Composition & Group & $\sum_{\text {tr }}$ & $\sum_{\mathbf{r}}$ & $\sum_{\mathrm{f}}$ & $\sum_{21}$ \\
\hline \multirow{2}{*}{$\mathrm{UO}_{2} 2.35 \mathrm{w} / \mathrm{o}$} & Fast & 0.25802 & 0.02891 & 0.00264 & 0.01918 \\
\hline & Thermal & 1.00140 & 0.07814 & 0.05200 & \\
\hline \multirow{2}{*}{$\mathrm{UO}_{2} 3.40$ w/o, 88 IFBA, 24 BA } & Fast & 0.25750 & 0.02911 & 0.00327 & 0.01811 \\
\hline & Thermal & 1.00061 & 0.14153 & 0.06826 & \\
\hline \multirow{2}{*}{$\mathrm{UO}_{2} 3.40$ w/o, 28 IFBA, 24 BA } & Fast & 0.25749 & 0.02908 & 0.00328 & 0.01832 \\
\hline & Thermal & 0.99954 & 0.13309 & 0.06976 & \\
\hline \multirow{2}{*}{$\mathrm{UO}_{2} 4.45$ w/o, 88 IFBA, 12 BA } & Fast & 0.25713 & 0.02929 & 0.00389 & 0.01762 \\
\hline & Thermal & 1.00322 & 0.14440 & 0.08461 & \\
\hline \multirow{2}{*}{$\mathrm{UO}_{2} 4.45$ w/o, 72 IFBA, 24 BA } & Fast & 0.25712 & 0.02922 & 0.00389 & 0.01762 \\
\hline & Thermal & 1.00268 & 0.15511 & 0.08506 & \\
\hline \multirow{2}{*}{$\mathrm{UO}_{2} 4.45$ w/o, 88 IFBA, 9 BA } & Fast & 0.25713 & 0.02931 & 0.00389 & 0.01764 \\
\hline & Thermal & 1.00322 & 0.14101 & 0.08461 & \\
\hline \multirow{2}{*}{$\mathrm{UO}_{2} 4.45$ w/o, 112 IFBA } & Fast & 0.25713 & 0.02937 & 0.00388 & 0.01760 \\
\hline & Thermal & 1.00402 & 0.13388 & 0.08393 & \\
\hline \multirow{2}{*}{$\mathrm{UO}_{2} 3.40$ w/o, 44 IFBA, 24 BA } & Fast & 0.25749 & 0.02909 & 0.00328 & 0.01827 \\
\hline & Thermal & 0.99983 & 0.13534 & 0.06936 & \\
\hline \multirow{2}{*}{$\mathrm{UO}_{2} 2.35$ w/o, 28 IFBA } & Fast & 0.25802 & 0.02893 & 0.00263 & 0.01907 \\
\hline & Thermal & 1.00127 & 0.08272 & 0.05143 & \\
\hline
\end{tabular}

Table (3-b): Macroscopic Cross-section - (Th-Pu) $\mathrm{O}_{2}$ Fuel Blanket Compositions

\begin{tabular}{|c|l|l|l|l|l|}
\hline Composition & \multicolumn{1}{|c|}{ Group } & $\sum_{\text {tr }}$ & $\sum_{\mathbf{r}}$ & $\sum_{\mathbf{f}}$ & $\sum_{\mathbf{2 1}}$ \\
\hline \multirow{2}{*}{$(\mathrm{Th}-\mathrm{Pu}) \mathrm{O}_{2}, 88 \mathrm{IFBA}, 12 \mathrm{BA}$} & Fast & 0.25394 & 0.02850 & 0.00363 & 0.01551 \\
\cline { 2 - 6 } & Thermal & 1.16533 & 0.28246 & 0.16522 & \\
\hline \multirow{2}{*}{$(\mathrm{Th}-\mathrm{Pu}) \mathrm{O}_{2}, 72 \mathrm{IFBA}, 24 \mathrm{BA}$} & Fast & 0.25393 & 0.02837 & 0.00363 & 0.01551 \\
\cline { 2 - 6 } & Thermal & 1.16419 & 0.28631 & 0.16558 & \\
\hline \multirow{2}{*}{$(\mathrm{Th}-\mathrm{Pu}) \mathrm{O}_{2}, 88 \mathrm{IFBA}, 9 \mathrm{BA}$} & Fast & 0.25394 & 0.02854 & 0.00363 & 0.01552 \\
\cline { 2 - 6 } & Thermal & 1.16533 & 0.28091 & 0.16522 & \\
\hline \multirow{2}{*}{$(\mathrm{Th}-\mathrm{Pu})_{2}, 112$ IFBA } & Fast & 0.25394 & 0.02865 & 0.00363 & 0.01549 \\
\cline { 2 - 6 } & Thermal & 1.16703 & 0.27934 & 0.16469 & \\
\hline
\end{tabular}

Table (3-c): Macroscopic Cross-section - (Th-Pu) $\mathrm{O}_{2}$ Fuel Ring Compositions

\begin{tabular}{|c|l|l|l|l|l|}
\hline Composition & \multicolumn{1}{|c|}{ Group } & \multicolumn{1}{c|}{$\sum_{\text {tr }}$} & $\sum_{\mathbf{r}}$ & $\sum_{\mathbf{f}}$ & $\sum_{\mathbf{2 1}}$ \\
\hline \multirow{2}{*}{$(\mathrm{Th}-\mathrm{Pu}) \mathrm{O}_{2}$} & Fast & 0.20211 & 0.02614 & 0.00204 & 0.01770 \\
\cline { 2 - 6 } & Thermal & 1.02230 & 0.15718 & 0.09865 & \\
\hline \multirow{2}{*}{$(\mathrm{Th}-\mathrm{Pu}) \mathrm{O}_{2}, 88 \mathrm{IFBA}, 24 \mathrm{BA}$} & Fast & 0.25394 & 0.02838 & 0.00363 & 0.01547 \\
\cline { 2 - 6 } & Thermal & 1.16533 & 0.28831 & 0.16522 & \\
\hline \multirow{2}{*}{$(\mathrm{Th}-\mathrm{Pu}) \mathrm{O}_{2}, 28 \mathrm{IFBA}, 24 \mathrm{BA}$} & Fast & 0.25392 & 0.02835 & 0.00364 & 0.01562 \\
\cline { 2 - 6 } & Thermal & 1.16109 & 0.28081 & 0.16655 & \\
\hline \multirow{2}{*}{$(\mathrm{Th}-\mathrm{Pu}) \mathrm{O}_{2}, 112 \mathrm{IFBA}$} & Fast & 0.25394 & 0.02865 & 0.00363 & 0.01549 \\
\cline { 2 - 6 } & Thermal & 1.16703 & 0.27934 & 0.16469 & \\
\hline \multirow{2}{*}{$(\mathrm{Th}-\mathrm{Pu}) \mathrm{O}_{2}, 44 \mathrm{IFBA}, 24 \mathrm{BA}$} & Fast & 0.25393 & 0.02836 & 0.00364 & 0.01558 \\
\cline { 2 - 6 } & Thermal & 1.16222 & 0.28281 & 0.16620 & \\
\hline \multirow{2}{*}{$(\mathrm{Th}-\mathrm{Pu}) \mathrm{O}_{2}, 28 \mathrm{IFBA}$} & Fast & 0.25392 & 0.02861 & 0.00364 & 0.01571 \\
\cline { 2 - 6 } & Thermal & 1.16109 & 0.26789 & 0.16655 & \\
\hline
\end{tabular}

\section{Feedback model}

A feedback model is an analytical approximation for the dependence of any macroscopic crosssection (including discontinuity factors) upon the thermal-hydraulic variables. The coefficient-based feedback model, involving fuel temperature, coolant temperature is defined as:

$$
\Sigma=\Sigma^{*}+\frac{\partial \Sigma}{\partial T_{f}}\left(T_{f}-T_{f}^{*}\right)+\frac{\partial \Sigma}{\partial T_{c}}\left(T_{c}-T_{c}^{*}\right)
$$

where $\Sigma$ represents any of the following groupdependent macroscopic nuclear parameters: 
- diffusion coefficient (D) or transport cross$\operatorname{section}\left(\Sigma_{\mathrm{tr}}\right)$,

- capture cross-section $\left(\Sigma_{c}\right)$,

- scattering removal cross-section $\left(\Sigma_{\mathrm{r}}\right)$,

- neutron production (nufission) cross-section $\left(v \Sigma_{\mathrm{f}}\right)$,

- fission cross-section $\left(\Sigma_{\mathrm{f}}\right)$,

$\Sigma^{*}, T_{f}^{*}, T_{c}^{*}$ are reference values.

The feedback coupling between neutronics and thermal-hydraulic is characterized by the definition of channel region. In the present work, each fuel assembly is defined as channel region. The channel map for $1 / 8$ core (26 channels) is shown in Fig.(3). The channels are classified into three types, namely: whole channels, half channels and half quarter channels (at the center of the core). The channels which are split vertically and those which are split diagonally are considered to be similar since the flow area, wetted and heated perimeter, and the number of heated rods are the same for both. The types of channels and fuels for the three core loading patterns are presented in Table (4).

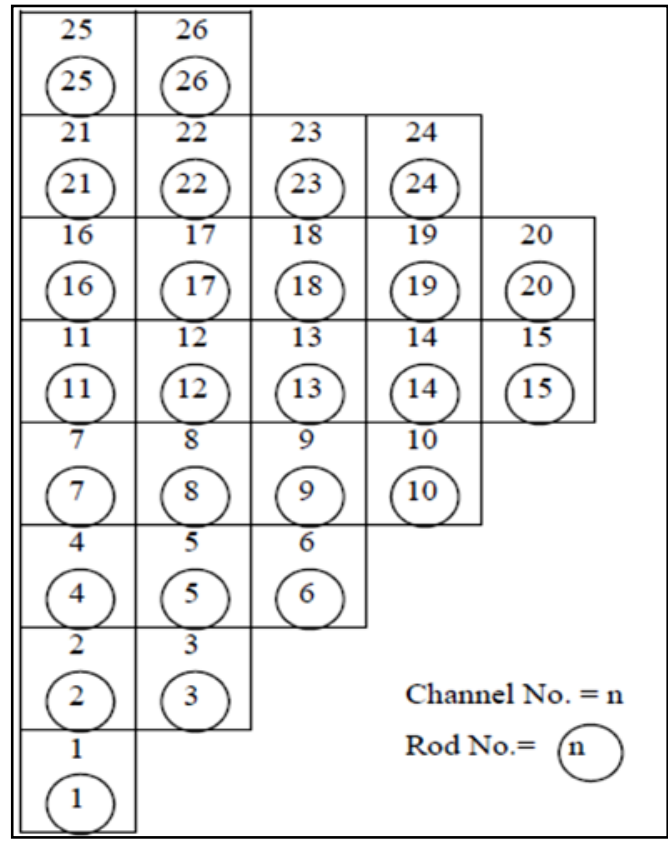

Fig. (3): Channel Map

Table (4): Channels and fuel Types

\begin{tabular}{|l|l|l|l|}
\hline Loading Pattern & \multicolumn{1}{|c|}{ Channel } & Fuel Type & \multicolumn{1}{c|}{ Channel Numbers } \\
\hline \multirow{3}{*}{$\mathrm{UO}_{2}$} & whole channel & $\mathrm{UO}_{2}$ & $5,8,9,12,13,14,17,18,19,20,22,23,24,26$ \\
\cline { 2 - 4 } & half channel & $\mathrm{UO}_{2}$ & $2,3,4,6,7,10,11,15,16,21,25$ \\
\cline { 2 - 4 } & half quarter channel & $\mathrm{UO}_{2}$ & 1 \\
\hline \hline \multirow{4}{*}{$\mathrm{UO}_{2} /(\mathrm{Th}-\mathrm{Pu}) \mathrm{O}_{2}$ (Blanket) } & whole channel & $\mathrm{UO}_{2}$ & $5,8,9,12,13,14,17,18$ \\
\cline { 2 - 4 } & whole channel & $(\mathrm{Th}-\mathrm{Pu}) \mathrm{O}_{2}$ & $19,20,22,23,24,26$ \\
\cline { 2 - 4 } & half channel & $\mathrm{UO}_{2}$ & $2,3,4,6,7,10,11,15,16,21$ \\
\cline { 2 - 4 } & half channel & $(\mathrm{Th}-\mathrm{Pu}) \mathrm{O}_{2}$ & 25 \\
\cline { 2 - 4 } & half quarter cannel & $\mathrm{UO}_{2}$ & 1 \\
\hline \hline \multirow{3}{*}{$\mathrm{UO}_{2} /(\mathrm{Th}-\mathrm{Pu}) \mathrm{O}_{2}$ (Ring) } & whole channel & $\mathrm{UO}_{2}$ & $5,8,9,22,23,24,25,26$ \\
\cline { 2 - 4 } & whole channel & $(\mathrm{Th}-\mathrm{Pu}) \mathrm{O}_{2}$ & $12,13,14,17,18,19,20$ \\
\cline { 2 - 4 } & half channel & $\mathrm{UO}_{2}$ & $2,3,4,6,7,10,11,21$ \\
\cline { 2 - 4 } & half channel & $(\mathrm{Th}-\mathrm{Pu}) \mathrm{O}_{2}$ & 15,16 \\
\cline { 2 - 4 } & half quarter channel & $\mathrm{UO}_{2}$ & 1 \\
\hline
\end{tabular}

\section{Results and Discussion}

The results obtained for the steady state analysis are summarized in table (5). Normalized assembly averaged power density for $1 / 8$ core was calculated for the three loading patterns using QUARK code, and can be seen in Fig.(4). This parameter calculated values were compared with those from the DCD [9]. The maximum difference obtained is statistically insignificant, as can be noticed in the following: 0.011 for $\mathrm{UO}_{2}$ loading pattern, and 0.059 and 0.014 for the $\mathrm{UO}_{2} /(\mathrm{Th}-\mathrm{Pu}) \mathrm{O}_{2}$ blanket and $\mathrm{UO}_{2} /(\mathrm{Th}-\mathrm{Pu}) \mathrm{O}_{2}$ ring loading patterns, respectively. Fig. (5) presents the axial normalized peak power density with the peak at nodes $(5,1,12),(1,1,12),(1,6,12)$ for $\mathrm{UO}_{2}, \mathrm{UO}_{2} /$ (Th$\mathrm{Pu} \mathrm{O}_{2}$ blanket and $\mathrm{UO}_{2} /(\mathrm{Th}-\mathrm{Pu}) \mathrm{O}_{2}$ ring core loading patterns, respectively. Fig. (6) shows the radial thermal flux distribution for $1 / 8$ core corresponding to the considered loading patterns. 
HALA K. SELIM et al.

Table(5): Summary Results for Steady State Calculation

\begin{tabular}{|c|c|c|c|}
\hline Parameter & $\mathbf{U O}_{2}$ & $\begin{array}{r}\mathrm{UO}_{2} /(\mathrm{Th}-\mathrm{Pu}) \mathrm{O}_{2} \\
\text { (Blanket) }\end{array}$ & $\begin{array}{c}\mathrm{UO}_{2} /(\mathrm{Th}-\mathrm{Pu}) \mathrm{O}_{2} \\
\text { (Ring) }\end{array}$ \\
\hline Average total nodal flux (n/ $\left.\mathrm{cm}^{2} . \mathrm{s}\right)$ & $2.095 \mathrm{E}+14$ & $2.122 \mathrm{E}+14$ & $2.075 \mathrm{E}+14$ \\
\hline Mean power density $\left(\mathrm{MW} / \mathrm{cm}^{3}\right)$ & 110.819 & 110.819 & 110.819 \\
\hline Mean pressure drop $(\mathrm{kPa})$ & 98.573 & 99.926 & 98.817 \\
\hline Mean hydrostatic head (kPa) & 29.642 & 29.411 & 29.642 \\
\hline Average fuel temperature $(\mathrm{K})$ & 846.97 & 842.47 & 834.13 \\
\hline Maximum fuel temperature (K) & 1095.41 & 1290.27 & 1190.09 \\
\hline Average doppler temperature (K) & 714.51 & 711.73 & 707.05 \\
\hline Maximum doppler temperature (K) & 845.30 & 949.03 & 896.23 \\
\hline Maximum fuel enthalpy (MJ/kg) - (cal/g) & $0.233--55.784$ & $0.296-70.703$ & $0.264-63.007$ \\
\hline Average coolant temperature (K) & 579.18 & 578.87 & 578.84 \\
\hline Average coolant density (g/cm3) & 0.7083 & 0.7028 & 0.7074 \\
\hline Average exit coolant temperature (K) & 601.78 & 600.32 & 600.86 \\
\hline Average exit coolant density (g/cm3) & 0.6485 & 0.6209 & 0.6416 \\
\hline $\begin{array}{l}\text { Average linear heat rate per fuel rod } \\
(\mathrm{kW} / \mathrm{m})\end{array}$ & 19.223 & 19.223 & 18.746 \\
\hline Maximum axial hot channel factor & 1.497 & 1.496 & 1.492 \\
\hline Maximum radial hot channel factor & 1.270 & 1.730 & 1.720 \\
\hline Power Peaking Factor & 1.901 & 2.588 & 2.566 \\
\hline
\end{tabular}

$\mathrm{UO}_{2}$ - Ref.

$\mathrm{UO}_{2}$

$\mathrm{UO}_{2} /(\mathrm{Th}-\mathrm{Pu}) \mathrm{O}_{2}$ - Blanket

\begin{tabular}{|c|c|c|c|c|}
\hline $\begin{array}{l}0.541 \\
0.536 \\
0.566 \\
0.535 \\
\end{array}$ & $\begin{array}{l}0.439 \\
0.435 \\
0.459 \\
0.434 \\
\end{array}$ & & & \\
\hline 0.957 & 0.913 & 0.815 & 0.561 & \\
\hline 0.949 & 0.905 & 0.808 & 0.556 & \\
\hline 1.001 & 0.955 & 0.852 & 0.587 & \\
\hline 0.946 & 0.903 & 0.806 & 0.555 & \\
\hline 1.161 & 1.168 & 1.026 & 1.041 & 0.630 \\
\hline 1.151 & 1.158 & 1.017 & 1.032 & 0.625 \\
\hline 1.214 & 1.221 & 1.073 & 1.089 & 0.659 \\
\hline 1.148 & 1.155 & 1.015 & 1.029 & 0.623 \\
\hline 1.254 & 1.113 & 1.203 & 1.033 & 0.859 \\
\hline 1.243 & 1.104 & 1.193 & 1.024 & 0.852 \\
\hline 1.311 & 1.164 & 1.258 & 1.080 & 0.898 \\
\hline 1.240 & 1.101 & 1.190 & 1.022 & 0.850 \\
\hline 1.130 & 1.250 & 1.111 & 1.193 & \\
\hline 1.120 & 1.239 & 1.102 & 1.183 & \\
\hline 1.182 & 1.307 & 1.162 & 1.248 & \\
\hline 1.118 & 1.236 & 1.099 & 1.180 & \\
\hline 1.268 & 1.142 & 1.250 & & \\
\hline 1.257 & 1.132 & 1.239 & & \\
\hline 1.326 & 1.194 & 1.307 & & \\
\hline 1.254 & 1.129 & 1.236 & & \\
\hline 1.154 & 1.273 & & & \\
\hline 1.144 & 1.262 & & & \\
\hline 1.207 & 1.331 & & & \\
\hline 1.141 & 1.259 & & & \\
\hline 1.279 & & & & \\
\hline 1.268 & & & & \\
\hline 1.338 & & & & \\
\hline 1.265 & & & & \\
\hline
\end{tabular}

$\mathrm{UO}_{2} /(\mathrm{Th}-\mathrm{Pu}) \mathrm{O}_{2}$ - Ring

Fig. (4): Normalized Assembly-Averaged Power Density for 1/8 Core 


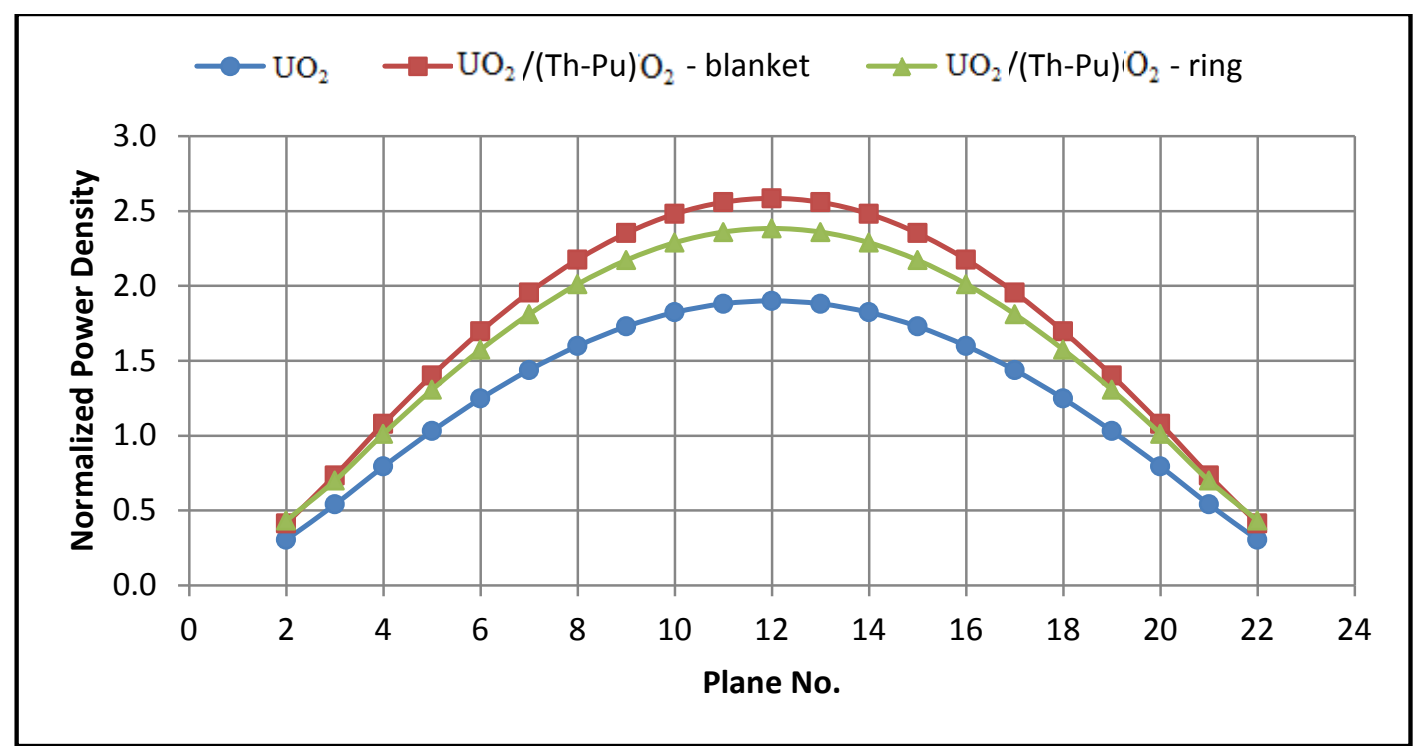

Fig. (5): Axial Normalized Peak Power Density

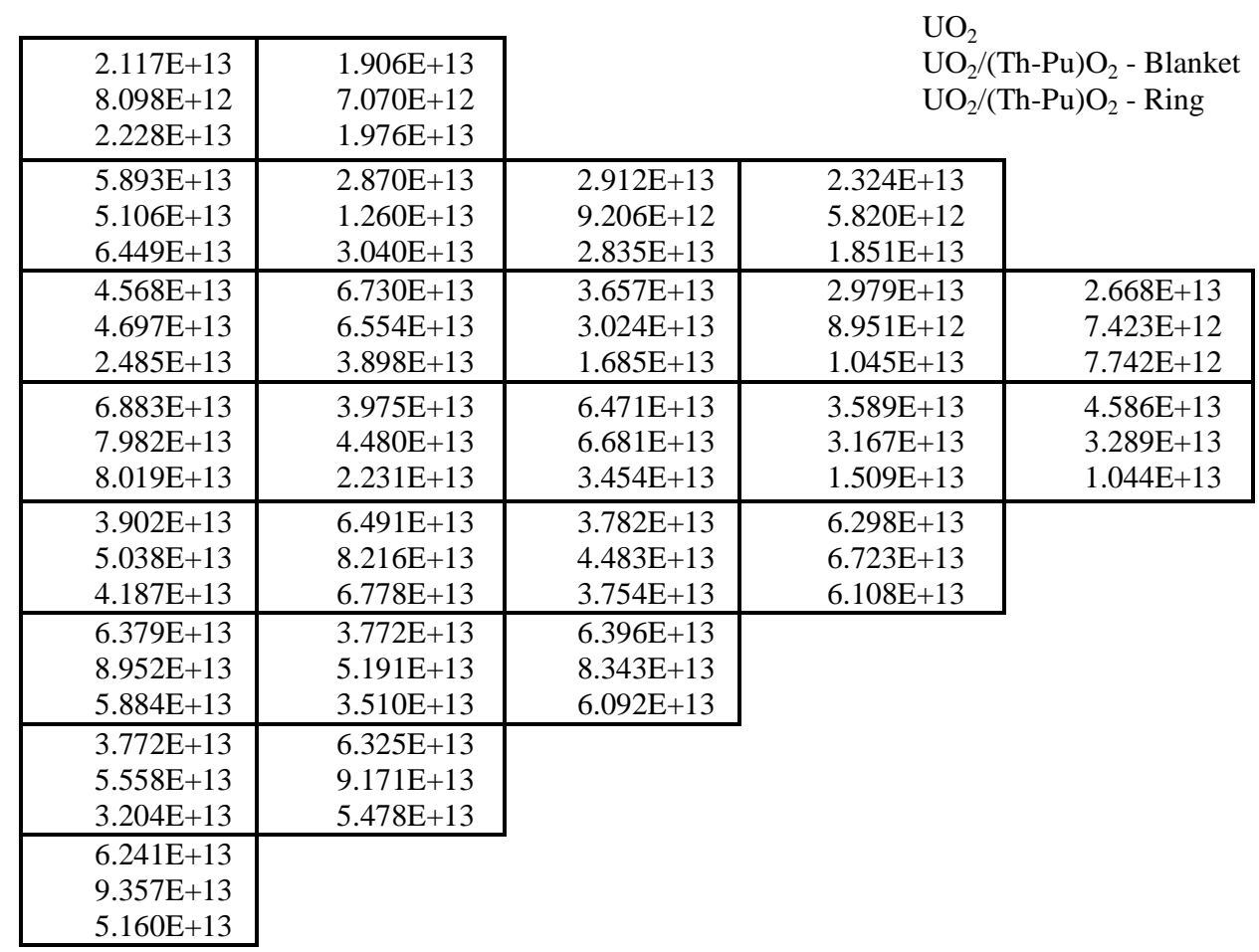

Fig. (6): Thermal Flux Distribution for 1/8 Core

\section{Nuclear hot channel factors}

It is important to note that replacing a third of AP1000 $\mathrm{UO}_{2}$ fuel assemblies with (Th-Pu) $\mathrm{O}_{2}$ fuel assemblies does not dramatically change the core's power distribution or induce hot channel factors beyond the prescribed limits. Local power density at the hottest part of a hot nuclear fuel rod should be estimated accurately to confirm that the rod does not melt.
The nuclear axial hot channel factor $\left(F_{Z}^{N}\right)$ is defined as: $F_{Z}^{N}=\frac{\text { Maximum heat flux of the hot channel }}{\text { Average heat flux of the hot channel }}$

- For $\mathrm{UO}_{2}, \mathrm{UO}_{2} /(\mathrm{Th}-\mathrm{Pu}) \mathrm{O}_{2}$ blanket and $\mathrm{UO}_{2} /(\mathrm{Th}$ $\mathrm{Pu} \mathrm{O}_{2}$ ring loading patterns, the axial hot channel factors of the core are $1.497,1.496$ and 1.492, respectively 
The nuclear radial hot channel factor $\left(F_{R}^{N}\right)$ is defined as:

$F_{R}^{N}$

$=\frac{\text { Average heat flux of the hot channel }}{\text { Average heat flux of the channels in the core }}$

- For $\mathrm{UO}_{2}, \mathrm{UO}_{2} /(\mathrm{Th}-\mathrm{Pu}) \mathrm{O}_{2}$ blanket and $\mathrm{UO}_{2} /(\mathrm{Th}$ $\mathrm{Pu}) \mathrm{O}_{2}$ ring loading patterns, the radial hot channel factors of the core are $1.27,1.73$ and 1.72 , respectively.

The Total nuclear hot channel factor (power peaking factors) $\left(F_{q}^{N}\right)$ is:

$F_{q}^{N}$

$=\frac{\text { Maximum heat flux of the hot channel }}{\text { Average heat flux of the channels in the core }}$ $=F_{Z}^{N} * F_{R}^{N}$

- For $\mathrm{UO}_{2}, \mathrm{UO}_{2} /(\mathrm{Th}-\mathrm{Pu}) \mathrm{O}_{2}$ blanket and $\mathrm{UO}_{2} /(\mathrm{Th}$ $\mathrm{Pu}) \mathrm{O}_{2}$ ring loading patterns, the hot channel factors of the core (power peaking factor) are 1.901, 2.588 and 2.566, respectively, which are under the design limit, 2.6 .

\section{Critical heat flux (CHF)}

There are strict regulatory requirements concerning the flux and power distributions in power reactors. Likewise, to ensure that there is no risk of fuel melting, the fuel centerline temperature must be kept well within the melting temperature of the fuel. This requirement is met by ensuring that the critical heat flux is never reached. CHF describes a thermal limit where a phase change in the reactor coolant occurs during heating. The CHF occurs when the bubble density from nucleate boiling in the boundary layer of a fuel rod is so great that adjacent bubbles coalesce and form a vapor film on the surface of the rod. Heat transfer across the vapor film is relatively low compared to the liquid, and the occurrence of CHF is accompanied by a marked increase in the cladding surface temperature. Under such conditions, a rapid oxidation (or even melting) of the cladding can take place. The critical heat flux is reflected in the departure from nucleate boiling ratio (DNBR), defined as the ratio between the CHF (the heat flux is needed to cause departure from nucleate boiling) and the local heat flux of a fuel rod. The CHF summary is presented in Table (6) (W-3 correlation is used for CHF). The axial MDNBR of the hot channel is presented in Fig. (7). Over the length of the hot channel $(4.166 \mathrm{~m})$, the DNBR varies with a minimum of 2.887, 1.561 and 1.957, respectively, for $\mathrm{UO}_{2}, \mathrm{UO}_{2} /(\mathrm{Th}-\mathrm{Pu}) \mathrm{O}_{2}$ blanket and $\mathrm{UO}_{2} /(\mathrm{Th}-\mathrm{Pu}) \mathrm{O}_{2}$ ring loading patterns, values are greater than those in the design limit, 1.3.

Each fuel assembly is defined as a channel region. The axial average fuel assembly temperature is shown in Fig. (8) and the axial average fuel temperature for the hottest fuel rod with the maximum enthalpy can be seen in Fig. (9). Maximum enthalpy take values equal to (0.233 $\mathrm{MJ} / \mathrm{kg}$ - $55.784 \mathrm{cal} / \mathrm{g}),(0.296 \mathrm{MJ} / \mathrm{kg}$ - 70.703 $\mathrm{cal} / \mathrm{g}),(0.264 \mathrm{MJ} / \mathrm{kg}-63.007 \mathrm{cal} / \mathrm{g})$ for $\mathrm{UO}_{2}$, $\mathrm{UO}_{2} /(\mathrm{Th}-\mathrm{Pu}) \mathrm{O}_{2}$ blanket and $\mathrm{UO}_{2} /(\mathrm{Th}-\mathrm{Pu}) \mathrm{O}_{2}$ ring loading patterns, respectively.

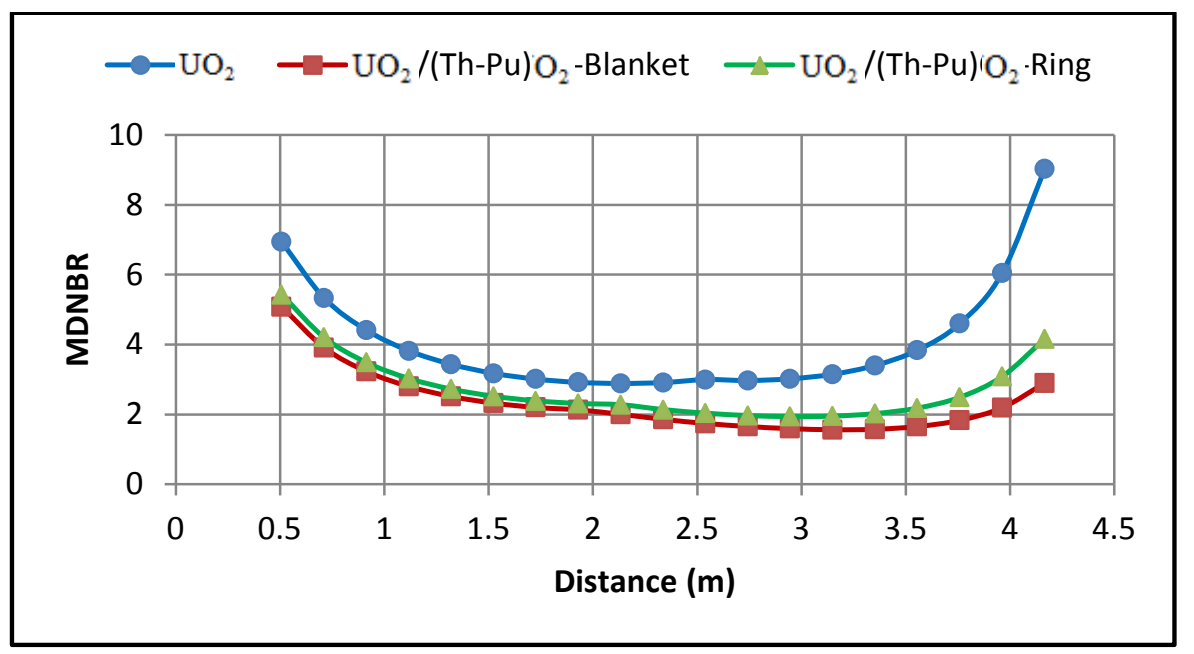

Fig.(7): Axial MDNBR of the Hot Channel 
Using Thorium Based Fuel In AP1000.....

Table (6): Axial Critical Heat Flux Summary

\begin{tabular}{|c|c|c|c|c|c|c|}
\hline \multirow[b]{2}{*}{$\begin{array}{l}\text { Distance } \\
\text { (m) }\end{array}$} & \multicolumn{3}{|c|}{ Flux $\left(\mathrm{MW} / \mathrm{m}^{2}\right)$} & \multicolumn{3}{|c|}{ MDNBR } \\
\hline & $\mathbf{U O}_{2}$ & $\begin{array}{c}\mathrm{UO}_{2} /(\mathrm{Th}-\mathrm{Pu}) \mathrm{O}_{2} \\
\text { (Blanket) }\end{array}$ & $\begin{array}{c}\mathrm{UO}_{2} /(\mathrm{Th}-\mathrm{Pu}) \mathrm{O}_{2} \\
\text { (Ring) }\end{array}$ & $\mathbf{U O}_{2}$ & $\begin{array}{c}\mathrm{UO}_{2} /(\mathrm{Th}-\mathrm{Pu}) \mathrm{O}_{2} \\
\text { (Blanket) }\end{array}$ & $\begin{array}{c}\mathrm{UO}_{2} /(\mathrm{Th}- \\
\mathrm{Pu} \mathrm{O}_{2} \\
\text { (Ring) }\end{array}$ \\
\hline 0.508 & 0.511 & 0.695 & 0.652 & 6.937 & 5.083 & 5.432 \\
\hline 0.711 & 0.664 & 0.903 & 0.841 & 5.335 & 3.912 & 4.206 \\
\hline 0.914 & 0.803 & 1.093 & 1.014 & 4.412 & 3.231 & 3.487 \\
\hline 1.118 & 0.926 & 1.26 & 1.167 & 3.821 & 2.8 & 3.028 \\
\hline 1.321 & 1.03 & 1.402 & 1.296 & 3.436 & 2.513 & 2.724 \\
\hline 1.524 & 1.114 & 1.515 & 1.399 & 3.175 & 2.323 & 2.52 \\
\hline 1.727 & 1.174 & 1.598 & 1.474 & 3.011 & 2.199 & 2.388 \\
\hline 1.93 & 1.212 & 1.648 & 1.52 & 2.916 & 2.129 & 2.313 \\
\hline 2.134 & 1.223 & 1.665 & 1.536 & 2.887 & 2.002 & 2.277 \\
\hline 2.337 & 1.212 & 1.648 & 1.52 & 2.912 & 1.858 & 2.138 \\
\hline 2.54 & 1.174 & 1.598 & 1.474 & 2.996 & 1.741 & 2.035 \\
\hline 2.743 & 1.114 & 1.515 & 1.399 & 2.971 & 1.653 & 1.967 \\
\hline 2.946 & 1.03 & 1.402 & 1.296 & 3.019 & 1.592 & 1.937 \\
\hline 3.15 & 0.926 & 1.26 & 1.167 & 3.15 & 1.561 & 1.951 \\
\hline 3.353 & 0.803 & 1.093 & 1.014 & 3.403 & 1.574 & 2.023 \\
\hline 3.556 & 0.664 & 0.903 & 0.841 & 3.838 & 1.653 & 2.181 \\
\hline 3.759 & 0.511 & 0.695 & 0.652 & 4.602 & 1.831 & 2.49 \\
\hline 3.962 & 0.348 & 0.472 & 0.45 & 6.049 & 2.191 & 3.085 \\
\hline 4.166 & 0.196 & 0.266 & 0.278 & 9.03 & 2.897 & 4.164 \\
\hline
\end{tabular}

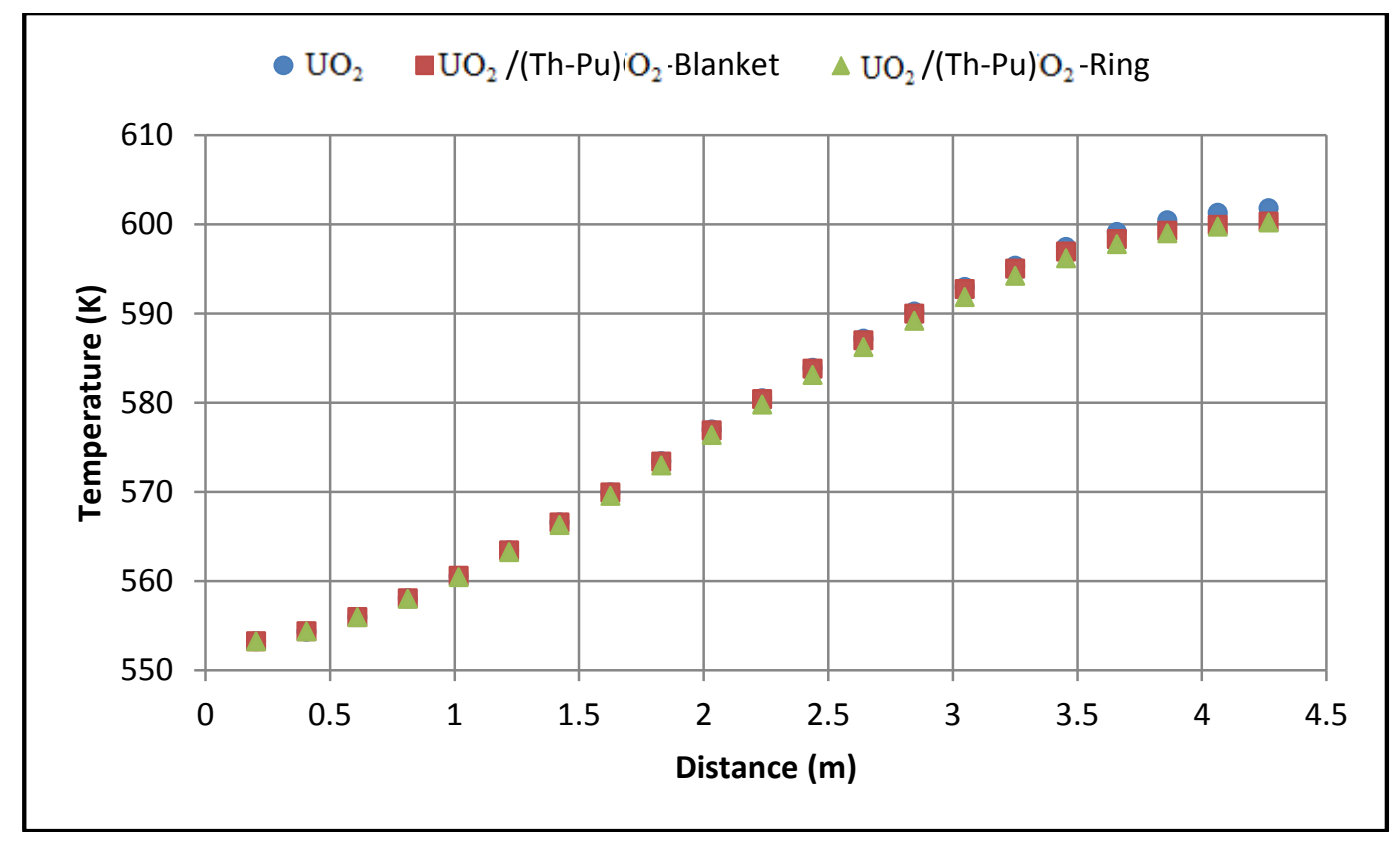

Fig.(8): Axial Average Fuel Assembly Temperature 


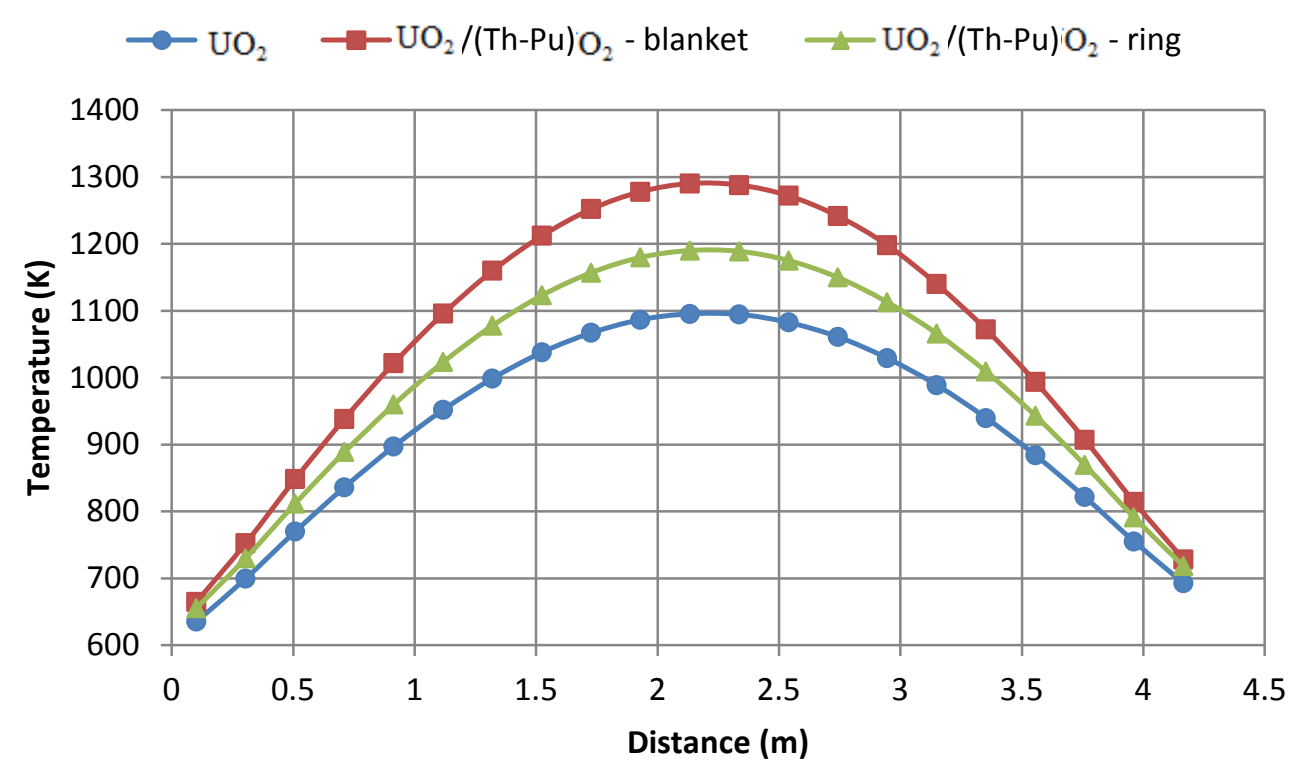

Fig.( 9): Axial Average Temperature for Hot Fuel Rod

\section{Conclusion}

The results of the performed steady state analysis show that the two considered arrangements for (Th-Pu) $\mathrm{O}_{2}$ fuel assemblies loading in the core $\left(\mathrm{UO}_{2} /(\mathrm{Th}-\mathrm{Pu}) \mathrm{O}_{2}\right.$ blanket and $\mathrm{UO}_{2} /(\mathrm{Th}-\mathrm{Pu}) \mathrm{O}_{2}$ ring core loading schemes) can be used in AP1000, as the safety criteria mentioned in design control document are met.

The hot channel factors have a significant impact on the nuclear reactor safety margin and they affect the core thermal hydraulic design. These factors must remain below the design safety limits of the core during normal operation. In the present study, the power peaking factor was calculated for the considered $\mathrm{UO}_{2} /(\mathrm{Th}-\mathrm{Pu}) \mathrm{O}_{2}$ blanket and $\mathrm{UO}_{2} /(\mathrm{Th}-\mathrm{Pu}) \mathrm{O}_{2}$ ring loading patterns, the results indicate that the maximum value remains below the design limit, thus provides an adequate safety margin.

The Departure from Nucleate Boiling Ratio (DNBR) of the system is an important engineering design parameter for pressurized water reactors. The results of this study show that the calculated DNBR value for $\mathrm{UO}_{2} /(\mathrm{Th}-\mathrm{Pu}) \mathrm{O}_{2}$ blanket and $\mathrm{UO}_{2} /(\mathrm{Th}-\mathrm{Pu}) \mathrm{O}_{2}$ ring loading patterns is above the design limits.

This work provides the necessary basis for the study on Th-based fuel behavior and thermal hydraulic analysis of AP1000 using Th-based fuel to evaluate the safety aspect of various core loading patterns under anticipated and accidental conditions.

\section{References}

1- IAEA-TECDOC-1349, International Atomic Energy Agency Potential of thorium-based fuel cycles to constrain plutonium and reduce long lived waste toxicity (2003).

2- IAEA-TECDOC- 1450, International Atomic Energy Agency Thorium fuel cycle - Potential benefits and challenges (2005).

3- IAEA-TECDOC-1496, International Atomic Energy Agency Thermophysical properties database of materials for light water reactors and heavy water reactors (2006).

4- Klara Insulander Bjork Thorium-plutonium fuel for long operating cycles in PWRs - preliminary calculations, The Southern African Institute of Mining and Metallurgy, Thorium and Rare Earths(2012).

5- CheukWah Lau, Henrik Nylén, Klara Insulander Björk and Urban Sandberg Feasibility study of $1 / 3$ thorium-plutonium mixed oxide core, Hindawi Publishing Corporation, Science and Technology of Nuclear Installations(2014).

6- A. Naymushin, YU. Chertkov, I. Lebedev, M. Anikin and S. Savanyuk Use of thorium in thermalneutron reactors: different types of fuel compositions in VVER-1000 reactor cell, Jr. of Industrial Pollution Control(2016).

7- IAEA-TECDOC-1578, International Atomic Energy Authority Computational Analysis of the 
Behavior of Nuclear Fuel under Steady State, Transient and Accident Conditions (2007).

8- Omid Noori-Kalkhoran, Abdolhamid Minuchehr, Amir Saied Shirani and M. Rahgoshay Full scope thermal-neutronic analysis of LOFA in a WWER1000 reactor core by coupling PARCS v2.7 and COBRA-EN, Progress in Nuclear Energy, 74, pp. 193-200(2014).

9- Westinghouse European design control document, Rev.1 (2011).
10- Advanced reactors information system, status report 81 Advanced Passive PWR AP1000, International Atomic Energy Authority (2011).

11- QUARK, code system for 2-Group, 3D neutronic kinetics calculations coupled to core thermal hydraulic, RSICC (2000).

12- WIMS-D5, Winfrith Improved Multigroup Scheme Code System, RSICC (1991). 